\title{
Effect of particle size and co-extractant on Momordica charantia extract yield and diffusion coefficient using supercritical $\mathrm{CO}_{2}$
}

\author{
Noor Aiysah Aris a, b, Ahmad Syahmi Zaini a, b, Hasmida Mohd Nasir a, Zuhaili Idham a, Yuvitha \\ Vellasamy ${ }^{\mathrm{b}}$, Mohd Azizi Che Yunus a, b,* \\ a Centre of Lipids Engineering and Applied Research (CLEAR), Ibnu Sina Institute for Scientific and Industrial Research, Universiti Teknologi \\ Malaysia, 81310 UTM Johor Bahru, Johor, Malaysia. \\ b Faculty of Chemical and Energy Engineering, Universiti Teknologi Malaysia, 81310 UTM Johor Bahru, Johor, Malaysia.
}

*Corresponding author: azizi@cheme.utm.my

\section{Article history}

Received 28 Mac 2018

Revised 20 May 2018

Accepted 3 July 2018

Published Online 3 September 2018

\section{Graphical abstract}

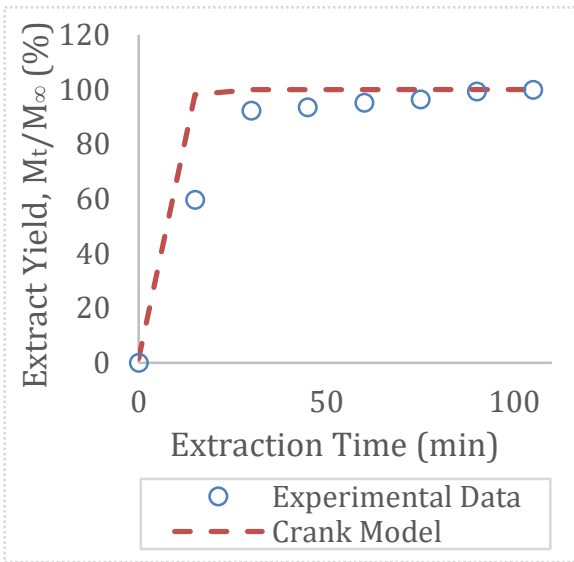

\begin{abstract}
Supercritical carbon dioxide $\left(\mathrm{SC}-\mathrm{CO}_{2}\right)$ is a fluid with high diffusivity and low viscosity which can penetrate deep into the solid particle efficiently compared to liquid or gas. $\mathrm{SC}-\mathrm{CO}_{2}$ is commonly used as a green solvent in modern extraction of bioactive compound from plants. Sometimes, a co-solvent was added in the system to increase solvent polarity or mix a co-extractant with dried sample to improve solute's transport properties. Hence, the aim of this study was to determine Momordica charantia extract yield with different mean particle size as well as diffusion coefficient, $D_{e}$, in the extraction process with and without co-extractant. Different mean particle sizes used were $0.2,0.3,0.5$, and $0.7 \mathrm{~mm}$ at constant operating condition (20 $\mathrm{MPa}, 65{ }^{\circ} \mathrm{C}$ and $4 \mathrm{~mL} / \mathrm{min}$ ). A feed-to-solvent (1:3) ratio was used in the extraction process with co-extractant. Based on the results, mean particle size of $0.3 \mathrm{~mm}$ gave the highest extract yield, $3.32 \%$ and $1.34 \%$ with and without co-extractant respectively. Whereas, the value of $D_{e}$ at $0.3 \mathrm{~mm}$ mean particle size, with and without co-extractant are $8.820 \times 10^{-12}$ and $7.920 \times$ $10^{-12} \mathrm{~m}^{2} / \mathrm{s}$ respectively. Therefore, $0.3 \mathrm{~mm}$ is the best mean particle size to produce the highest Momordica charantia extract yield and $D_{e}$ value in $\mathrm{SC}-\mathrm{CO}_{2}$ extraction with the presence of coextractant.
\end{abstract}

Keywords: Momordica charantia, co-extractant, supercritical carbon dioxide, particle size, diffusion coefficient.

\section{INTRODUCTION}

Diffusion coefficient, $D_{e}$, is one of the important parameters in describing mass transfer in supercritical fluid extraction (SFE) process (López-Padilla et al., 2016). According to Medina (2012), the variations of $D_{e}$ value from subcritical to supercritical region might due to chemical potential of solute which influence the diffusion flux, increase of density when heavier molecule of solute favours lighter solvent molecule in that region, and solute molecules form a cluster when near critical region forcing the solvent to move towards the region with solute's high concentration. Therefore, it is important to consider the $D_{e}$ value for the design and efficiency of the SFE process (Liong et al., 1991).

SFE is a modern green technology in extraction process because the end product comply the basic requirement for product's safety (Setapar et al., 2012). Ruslan et al. (2015) claimed that the extract from SFE is considered consumable and natural by the World Health Organization (WHO) and European Food and Drug Association (EFDA).Danlami et al. (2015) suggested that SFE is a green technology due to its chemical inertness, non-toxic and non-inflammable characteristics as well as less amount of solvent and sample used. Supercritical fluid such as carbon dioxide $\left(\mathrm{CO}_{2}\right)$ is commonly used as a solvent in the extraction process.
The main reason is because of its mild operating temperature and relatively low pressure condition. The critical temperature and pressure for carbon dioxide are $31{ }^{\circ} \mathrm{C}$ and $7.38 \mathrm{MPa}$ respectively. Furthermore, $\mathrm{CO}_{2}$ can easily be separated from the end product after depressurized (Yunus et al., 2015). Arsad et al. (2016) also agreed that by using SFE, the oil yield from piper betle leaves possess high percentage of antioxidant activity compared with conventional method. Therefore, SFE is the best extraction method in order to achieve higher quality of extract. Since $\mathrm{CO}_{2}$ is a non-polar solvent which favours mostly nonpolar compound, addition of co-solvent will increase its polarity and enhance the ability to extract more polar compound. Danlami et al. (2014) recommended the used of ethanol as a co-solvent due to its high miscibility with $\mathrm{CO}_{2}$ and allowed to be used in the food, cosmetic and pharmaceutical industries.

Sometimes, due to limitation of equipment, co-solvent cannot be used since it needs personal pump to operate and dissolve in $\mathrm{SC}-\mathrm{CO}_{2}$ before it enters the extraction vessel. Thus, a co-extractant is introduced to improve the transport properties of target compound into $\mathrm{SC}-\mathrm{CO}_{2}$ solvent bulk. Ciurlia et al. (2009) described the major difference in percentage yield of lycopene when using hazelnut oil as a co-solvent and co-extractant. Hazelnut oil as a co-extractant managed to extract $70 \%$ of lycopene instead of only $30 \%$ when it is used as a co-solvent. 
Moreover, as co-extractant, hazelnut oil accelerates the reaction to only 4 hours to achieve approximatey $70 \%$ of lycopene compared to when it is used as a co-solvent-it needs at least 6 hours to extract $30 \%$ of lycopene. Therefore, it is better to use co-extractant directly in the solid sample to improve solute transport properties in $\mathrm{SC}-\mathrm{CO}_{2}$ extraction.

Previous researcher used conventional method to extract bioactive compound in natural plants. Yasir et al. (2016) used orbital shaker to extract phenolic compound in Momordica dioica's seed with methanol and water as the solvent. Shanmugapriya and Poornima (2014) used a Soxhlet apparatus with ethanol as a solvent to extract charantin from Momordica charantia, an active compound known to lower the blood glucose. However, conventional method needs large amount of solvent and sample with long extraction time as well as low selectivity towards valuable target compound (Hadzri et al., 2014).

Momordica charantia L. (Cucurbitaceae) is a scientific name for bitter gourd which commonly known among local to treat diabetes mellitus due to its hypoglycemic effects (Zhang et al., 2015). Besides that, the extract from Momordica charantia could reduce body weight, improve glucose metabolism, and insulin signalling (Yang et al., 2015).

World of health organization (WHO) has estimated that the world population of diabetes patient will likely increase to 300 million or more by 2025 (Wang et al., 2014). Meanwhile in Malaysia, total diabetes patients has increased from $11.6 \%$ in 2006 to $15.2 \%$ in 2011 (Feisul \& Azmi, 2013). The prevalence percentage is expected to rise to $21.6 \%$ by 2020 (Bakar et al., 2015). It is important to choose a suitable extraction method to extract a valuable plant such as Momordica charantia. Hence, the aim of this study was to extract Momordica charantia with different mean particle sizes, using green technology of supercritical carbon dioxide $\left(\mathrm{SC}-\mathrm{CO}_{2}\right)$ solvent with and without co-extractant, to determine its extract yield and diffusion coefficient as well as the extraction efficiency of charantin in both conditions. Determination of diffusion coefficient was performed using Crank model. Meanwhile, high performance liquid chromatography (HPLC) was used to determine the extraction efficiency of charantin.

\section{EXPERIMENTAL}

\section{Materials}

Green bitter gourds (Momordica charantia) grown in Simpang Renggam (Johor, Malaysia) were purchased from a local market. The fruits were washed to eliminate any traces of impurities, cut into small pieces and dried in an oven (Memmert UFE 500) at $50{ }^{\circ} \mathrm{C}$ for $24 \mathrm{~h}$ (Fuangchan et al., 2011). The dried sample was then ground using commercial blender (Waring, U.S). The ground samples were sieved into 0.2, 0.3, 0.5, and $0.7 \mathrm{~mm}$ mean particle size using Endecotts Octagon 2000 Digital Sieve Shaker. The sample was then stored in a tight seal container inside the freezer $\left(-20^{\circ} \mathrm{C}\right)$ until the extraction day. Carbon dioxide (purity 99.99\%) was supplied by the Kras Instrument \& Service (Johor Bahru, Malaysia). Charantin (purity 98\%) standard was purchased from Wuhan Chemfaces Biochemical (Hubei, China). Pure $(100 \%)$ ethanol was purchased from Merck (Darmstadt, Germany).

\section{Supercritical Carbon Dioxide Extraction}

A pure ethanol was mixed with $5 \mathrm{~g}$ of Momordica charantia dried sample with a feed-to-solvent (1:3) ratio in the extractor vessel for the $\mathrm{SC}-\mathrm{CO}_{2}$ extraction with addition of co-extractant. While, $\mathrm{SC}-\mathrm{CO}_{2}$ extraction without addition of co-extractant was performed with pure $\mathrm{SC}-\mathrm{CO}_{2}$ solvent only (skipped mixing step of Momordica charantia dried sample and pure ethanol). The ratio of co-extractant and mass of sample were chosen based on limitation of equipment.

The supercritical carbon dioxide extraction was carried out at constant pressure of $20 \mathrm{MPa}$ and temperature of $65{ }^{\circ} \mathrm{C}$ using SFE laboratory apparatus shown in Fig. 1, which consisted of force ventilation oven (MMM Group, German) fitted with a $50 \mathrm{~mL}$ stainless steel extraction vessel. Pure 99.9\% $\mathrm{CO}_{2}$ gas (Mega Mount Industrial Gases Sdn Bhd, Malaysia) was liquidized using a refrigerated (cooler) bath circulator (Daihan Scientific. Co Ltd, Korea) and pumped to extraction vessel using carbon dioxide liquid pump (Tokyo, Japan) with a constant flow rate of $4 \mathrm{~mL} / \mathrm{min}$.
Pressure in the extraction vessel was regulated by means of a backpressure (Tescom Corp.,U.S) valve installed in the line between the extraction vessel and the separator. The depressurization process using control valve will convert the supercritical phase of carbon dioxide into its original phase with the help of water circulation bath (Daihan Scientific. Co Ltd, Korea) at the separator line which then separate the $\mathrm{CO}_{2}$ from the extracted sample. The extraction process was done dynamically for total extraction time of $105 \mathrm{~min}$ and oil yield were collected at every 15 min of interval times.

The Momordica charantia extract was weighed using the analytical balance (Ohaus, U.S) with an accuracy up to $0.0001 \mathrm{~g}$. The percentage of Momordica charantia extract yield was then calculated using Equation 1. The extract was later stored in a freezer $\left(-20^{\circ} \mathrm{C}\right)$ until further analysis.

$$
\text { Extract yield }(\%)=\frac{\text { Momordica charantia } \text { extract }(\mathrm{g})}{\text { Initial sample }(\mathrm{g})} \times 100
$$

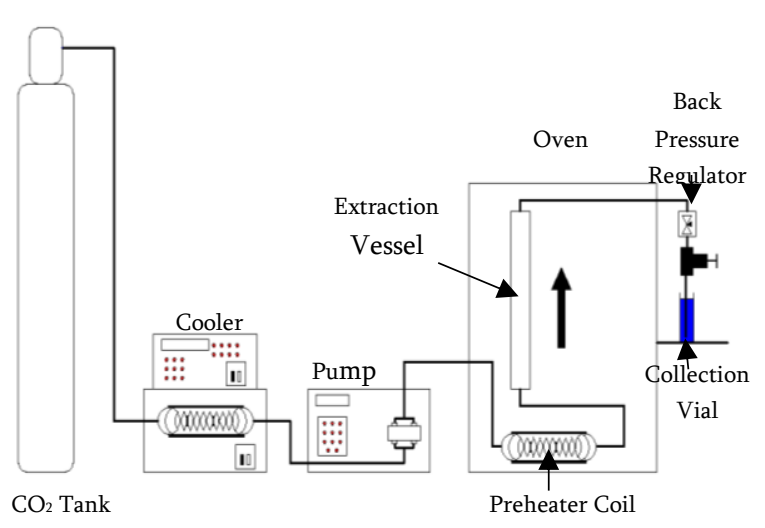

Fig. 1 Supercritical carbon dioxide extraction schematic diagram.

\section{High Performance Liquid Chromatography (HPLC)}

HPLC (Agilent 1260 Infinity, U.S) analysis was performed with C18 Inertsil ODS-3 column ( $5 \mu \mathrm{m}$ particle, $4.6 \mathrm{~mm} \times 250 \mathrm{~mm}$ ID). The mobile phase used was 100:2 (v/v) methanol-water and deliver at 1 $\mathrm{mL} / \mathrm{min}$ flow rate. The sample injection volume was $20 \mu \mathrm{L}$ using $\mathrm{UV}$ detection wavelength at $204 \mathrm{~nm}$.

\section{Crank Model}

Crank model was used to investigate the effect of particle size in influencing the mass transfer of solute-solvent in the fixed bed under supercritical condition. Crank (1975) has developed an equation to solve the diffusion in sphere when the surface concentration is maintained at constant by substituting diffusivity, $D$, with diffusion coefficient, $D_{e}$ (Santos et al., 1996).

Huang et al. (2011), Santos et al. (1996), Reverchon et al. (1993) and Bartle et al. (1990) summarized the assumptions for Crank model:

- All the single solid particle was assumed to be solid with constant similar size.

- The solute to be extracted was scattered uniformly inside the single solid particle and assumed to be at the same stage of extraction.

- The flow rate of supercritical fluid was fast enough to penetrate deep inside the solid particle with mass transfer resistance close to zero.

- Intra-particle mass transfer was the controlling factor in the extraction process.

- Axial dispersion is neglected

The total amount of diffusing molecule entering or leaving the sphere in non-steady state is given in Eq. 2.

$$
\frac{M_{t}}{M_{\infty}}=1-\frac{6}{\pi^{2}} \sum_{n=1}^{\infty} \frac{1}{n^{2}} \exp \left(-\frac{D_{e} n^{2} \pi^{2} t}{r^{2}}\right)
$$


where, $M_{t}$ is a total amount of solute diffused from sphere at time, $t$ in unit $\mathrm{g}, M_{\infty}$ is a total amount of solute in unit $\mathrm{g}, n$ is a number of iterations, $D_{e}$ is a diffusion coefficient in unit $\mathrm{m}^{2} \mathrm{~s}^{-1}, r$ is a particle radius in metre and $t$ is time in second.

\section{Statistical Analysis}

The deviation between the calculated and experimental value was evaluated. Model with the lowest amount of absolute average relative deviation (AARD) will be the best model to be used for further research. The AARD formula is as stated in Eq. 3.

$$
\mathrm{AARD}=\frac{1}{N} \sum_{i=1}^{N}\left|\frac{y_{\text {calculated }}-y_{\text {experimental }}}{y_{\text {experimental }}}\right| \times 100
$$

where, $N$ is a total number of experimental data. While, $y_{\text {calculated }}$ and $y_{\text {experimental }}$ are the data obtained from model equations and experimental data, respectively at $i$ condition.

\section{RESULTS AND DISCUSSION}

\section{Effect of mean particle size in Momordica charantia extract yield}

Fig. 2 shows a percentage of Momordica charantia extract yield for all different mean particle sizes in $\mathrm{SC}-\mathrm{CO}_{2}$ extraction (with and without co-extractant) at constant pressure of $20 \mathrm{MPa}$ and temperature of $65^{\circ} \mathrm{C}$. From the figure, it shows that the $\mathrm{SC}-\mathrm{CO}_{2}$ (with co-extractant) extraction gave highest percentage of Momordica charantia extract yield compared with $\mathrm{SC}-\mathrm{CO}_{2}$ (without co- extractant) extraction. In fact, the time taken to reach plateau phase are shorten in $\mathrm{SC}-\mathrm{CO}_{2}$ (with co-extractant) extraction rather than in $\mathrm{SC}-\mathrm{CO}_{2}$ (without co-extractant) extraction.

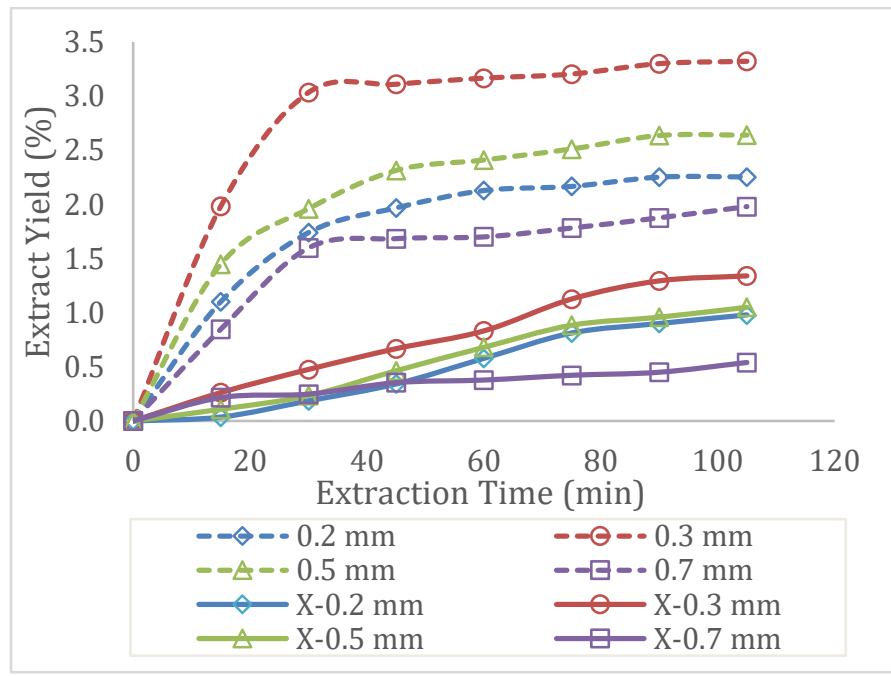

Fig. 2 Percentage of Momordica charantia extract yield in $\mathrm{SC}-\mathrm{CO}_{2}$ extraction (with and without co-extractant). X- denoted a SC- $\mathrm{CO}_{2}$ (without co-extractant) extraction.

In SC-CO 2 (with co-extractant) extraction, mean particle size of 0.3 $\mathrm{mm}$ gave the highest Momordica charantia extract yield, 3.32\% compared with other mean sizes as summarized in Table 2. Higher yield of extract can be obtained from particle size ranged from 0.3 to 0.5 ; below or above this range may cause a lower yield of extract. This might be due to the diffusion factor, where smaller particle size gives larger surface area and thus shorten the diffusion path for the solutesolvent to travel in comparison with larger particle size. Therefore, it is easier for the $\mathrm{SC}-\mathrm{CO}_{2}$ molecules to diffuse into and out of the smaller solid particle size.

The grinding process broke the cell walls of the solid particle, leading to more free solutes released onto the surface and easily dissolved in the $\mathrm{SC}-\mathrm{CO}_{2}$. Hence, the extract yield increases as the particle sizes were decreased by grinding. Özkal and Yener (2016) stated that the fraction of free solute released is represented by grinding efficiency, G, whereby more solute will be released when the particle size is decreasing due to more broken solid cells.

However, the smallest mean particle size of $0.2 \mathrm{~mm}$ which supposed to obtain the highest amount of oil yield among the other mean particle sizes can only obtain $2.25 \%$ extract yield after 105 min of extraction. The reason is because the solid particle is too compact for the $\mathrm{SC}-\mathrm{CO}_{2}$ molecules to penetrate into it. Kluson et al. (2012), pointed out that the decrease in the extract yield for smallest particle size is caused by solid particle compactness, and therefore $\mathrm{SC}-\mathrm{CO}_{2}$ molecules can only remove free solute on the solid surface only.

The same trend also occurred in SC- $\mathrm{CO}_{2}$ (without co- extractant) extraction as shown in Fig. 2 and Table 1. Mean particle size of $0.3 \mathrm{~mm}$ gives the highest Momordica charantia extract yield, 1.34\% compared with other mean sizes. The bigger particle sizes of $0.5 \mathrm{~mm}$ and $0.7 \mathrm{~mm}$ could only give a 1.05 and $0.54 \%$ of Momordica charantia extract yield. Meanwhile, the smallest mean particle size of $0.2 \mathrm{~mm}$ can only give a $0.98 \%$ of Momordica charantia extract yield.

Undoubtedly, mean particle size of $0.3 \mathrm{~mm}$ is the best particle for extraction of Momordica charantia in $\mathrm{SC}-\mathrm{CO}_{2}$ (with and without coextractant) extraction in order to get a higher extract yield.

\section{Diffusion coefficient, $D_{e}$ in $\mathrm{SC}-\mathrm{CO}_{2}$ (without co-extractant) extraction}

Table 1 lists the diffusion coefficient, $D_{e}$ value for different mean particle size used in the $\mathrm{SC}-\mathrm{CO}_{2}$ (without co-extractant) extraction. The $D_{e}$ value was determined by fitting the graph of extract yield percentage, $M_{t} / M_{\infty}$ for both experimental data and Crank model against extraction time as shown in Fig. 3. From the figure, Crank model predicted that the extraction curve will reach plateau phase at $80 \mathrm{~min}$. However, the experimental curve shows the opposite of the prediction. It seems that the extraction of Momordica charantia using $0.7 \mathrm{~mm}$ mean particle size will take a longer time to reach plateau phase.

Table 1 Summary of diffusion coefficient, $D_{e}$ and extract yield for different mean particle size, $d_{p}$ at $20 \mathrm{MPa}, 65^{\circ} \mathrm{C}$ and $4 \mathrm{~mL} / \mathrm{min}$ in SC-CO (without $^{-}$ co-extractant) extraction.

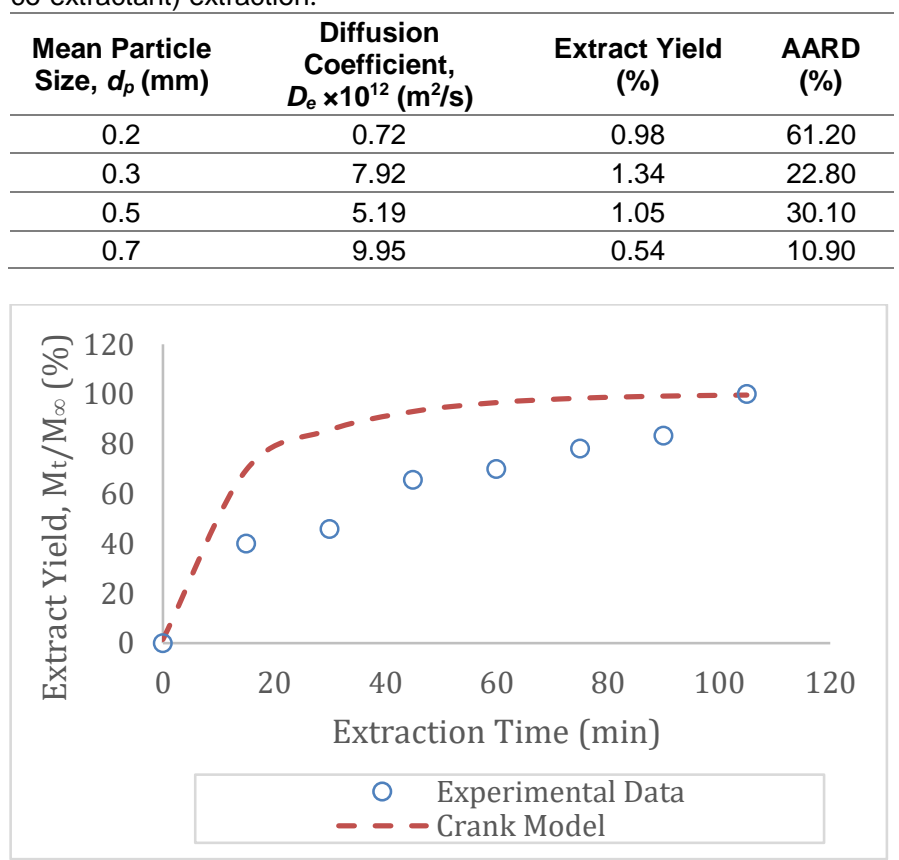

Fig. 3 Crank model for SC-CO $\mathrm{CO}_{2}$ extraction of Momordica charantia at 20 $\mathrm{MPa}, 65^{\circ} \mathrm{C}, 4 \mathrm{~mL} / \mathrm{min}, 0.7 \mathrm{~mm}$; fitted value $D_{e}=9.950 \times 10^{-12} \mathrm{~m}^{2} / \mathrm{s}$.

Furthermore, mean particle size of $0.7 \mathrm{~mm}$ gave the lowest percentage of extract yield among other sizes even though it does give the highest $D_{e}$ value, $9.950 \times 10^{12} \mathrm{~m}^{2} / \mathrm{s}$ as well as the lowest average absolute relative deviation (AARD), $10.9 \%$. In contrast, mean particle size of $0.3 \mathrm{~mm}$ which gave the highest extract yield among other size, has low $D_{e}$ value, $7.920 \times 10^{12} \mathrm{~m}^{2} / \mathrm{s}$ and higher AARD, $22.8 \%$. Suppossedly, higher $D_{e}$ value represent higher ability of solvent to penetrate into solid particle which then increase the extract yield. 
Unfortunately, the theory does not apply in this case. However, according to Nasir (2017), a diffusion equation does not necessarily gives an accurate description about the mechanism of extraction in natural plants since it is complex and not well defined. In fact, Vladić et al. (2016) stated that the fitting model is acceptable when the AARD value is up to $5 \sim 10 \%$ only. Above $10 \%$ indicates poor correlation between experimental data and fitted model. Therefore, Crank model failed to predict $D_{e}$ value for different mean particle size in $\mathrm{SC}-\mathrm{CO}_{2}$ (without co-extractant) extraction.

\section{Diffusion coefficient, $D_{e}$ in $\mathrm{SC}-\mathrm{CO}_{2}$ (with co-extractant) extraction}

Table 2 lists the $D_{e}$ value for all different mean particle sizes used in the $\mathrm{SC}-\mathrm{CO}_{2}$ (with co-extractant) extraction. It shows that mean particle size of $0.3 \mathrm{~mm}$ gave the highest $D_{e}$ value with low AARD which are $8.820 \times 10^{-12} \mathrm{~m}^{2} / \mathrm{s}$ and 5.968 respectively. While, Figure 4 shows the graph of extract yield, $M_{t} / M_{\infty}$ for both experimental data and Crank model against extraction time at mean particle size of $0.3 \mathrm{~mm}$.

From Figure 4, Crank model successfully predicted an extraction curve where it will only takes a $15 \mathrm{~min}$ to reach plateau phase compared with experimental as shown in Figure 3. Even tough from the experimental data, it took at least $75 \mathrm{~min}$ to reach plateau phase. It appears that, the model has successfully fitted with the experimental data and looks reliable. In fact, from Table 2 , the $D_{e}$ value and AARD for other mean particle sizes are within an acceptable range as mentioned by Vladić et al. (2016).

Table 2 Summary of diffusion coefficient, $D_{e}$ and extract yield for different mean particle size, $d_{p}$ at $20 \mathrm{MPa}, 65^{\circ} \mathrm{C}$ and $4 \mathrm{~mL} / \mathrm{min}$ in SC-CO $\mathrm{CO}_{2}$ with $1: 3$ ethanol as co-extractant.

\begin{tabular}{|c|c|c|c|}
\hline $\begin{array}{l}\text { Mean Particle } \\
\text { Size, } d_{p}(\mathrm{~mm})\end{array}$ & $\begin{array}{c}\text { Diffusion } \\
\text { Coefficient, } \\
D_{e} \times 10^{12}\left(\mathrm{~m}^{2} / \mathrm{s}\right)\end{array}$ & $\begin{array}{c}\text { Extract Yield } \\
(\%)\end{array}$ & $\begin{array}{c}\text { AARD } \\
(\%)\end{array}$ \\
\hline 0.2 & 2.19 & 2.25 & 7.23 \\
\hline 0.3 & 8.82 & 3.32 & 5.96 \\
\hline 0.5 & 4.99 & 2.64 & 5.17 \\
\hline 0.7 & 8.79 & 1.98 & 5.99 \\
\hline
\end{tabular}

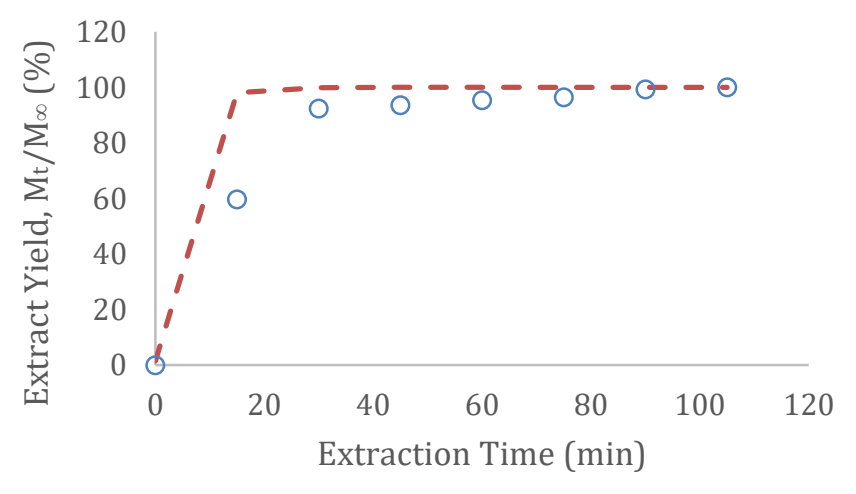

$$
\begin{aligned}
& \text { O Experimental Data } \\
& --\infty \text { Crank Model }
\end{aligned}
$$

Fig. 4 Crank model for $\mathrm{SC}-\mathrm{CO}_{2}$ (with co-extractant) extraction of Momordica charantia at $20 \mathrm{MPa}, 65^{\circ} \mathrm{C}, 4 \mathrm{~mL} / \mathrm{min}, 0.3 \mathrm{~mm}$; fitted value $D_{e}=8.820 \times 10^{-12} \mathrm{~m}^{2} / \mathrm{s}$.

According to Crank model in Eq. 2, particle radius, $r$ is directly proportional to the diffusion coefficient, $D_{e}$. Therefore, the smaller particle size will give higher $D_{e}$ value in the extraction process. On the contrary, mean particle size of $0.2 \mathrm{~mm}$ has the lowest $D_{e}$ value, $2.190 \times 10^{-12} \mathrm{~m}^{2} / \mathrm{s}$ indicates the difficulty of solvent to penetrate inside solid particle. As a matter of fact, for mean particle size of $0.2 \mathrm{~mm}$, even though it is the smallest particle size but the size is too fine and compact in the extraction vessel. As explained by Samadi and Vaziri (2017), fine particle will create a "chanelling" phenomenon due to adhesion effect. Adhesion effect happened when solid particles stick together and form a cake of solid particle, therefore restrict the interaction between solvent and solute in the extraction vessel and decrease the extract yield and $D_{e}$ value. Hence, the $D_{e}$ and extract yield values for mean particle size $0.2 \mathrm{~mm}$ are lower than mean particle size $0.3 \mathrm{~mm}$. Meanwhile, the larger mean particle size such as 0.5 and 0.7 $\mathrm{mm}$ will increase the mass transfer resistance due to their smaller surface area thereby decreasing the $D_{e}$ value and extract yield.

As mentioned previously, particle size influences the $D_{e}$ value in the extraction system. Silva and Delgado (2011) found that particle size is the most influence parameter in the diffusion coefficient in their study. They observed that the models used, deviate significantly from the experimental data in different particle size studied. Indeed, particle size influenced the diffusion coefficient in the extraction process. Hence, Crank model succesfully predict $D_{e}$ value for different mean particle size in $\mathrm{SC}_{-} \mathrm{CO}_{2}$ (with co-extractant) extraction.

\section{Effect of co-extractant in $\mathrm{SC}-\mathrm{CO}_{2}$ extraction}

In comparison, extraction process in $\mathrm{SC}-\mathrm{CO}_{2}$ (with co-extractant) extraction is more efficient in extracting Momordica charantia due to improvement of solute transport properties compared with the $\mathrm{SC}-\mathrm{CO}_{2}$ (without co-extractant) extraction. Moreover, the $D_{e}$ value and extract yield in $\mathrm{SC}-\mathrm{CO}_{2}$ (with co-extractant) extraction were higher and reliable compared with the $\mathrm{SC}-\mathrm{CO}_{2}$ (without co-extractant) extraction. Furthermore, the time taken to reach plateau phase for the extraction process is shorter in $\mathrm{SC}-\mathrm{CO}_{2}$ (with co-extractant) extraction rather than in $\mathrm{SC}-\mathrm{CO}_{2}$ (without co-extractant) extraction.

The reason is due to the addition of co-extractant directly in solid sample which probably gaves the swollen effect so that the solute easily transported out of solid matrix. Park et al. (2007) showed that the swollen effect by addition of co-extractant in green tea solid matrix helps caffeine to be easily transported out of the solid matrix and facilitate through the $\mathrm{SC}-\mathrm{CO}_{2}$ solvent bulk.

Another reason would be that the co-extractant changed the transport properties of solute and at the same time act as a co-solvent to increase solvent strength of SC-CO 2 solvent. Melo et al. (2014) stated that ethanol is a polar substance commonly used in food, cosmetic or pharmaceutical industries. It can increase the polarity of $\mathrm{SC}-\mathrm{CO}_{2}$ even with only small amount added. Durante et al. (2014) proposed that the oil in the pumpkin seed facilitates the transport of carotenoid from pumpkin flesh and probably improves the polarity of $\mathrm{SC}-\mathrm{CO}_{2}$ by acting as a co-solvent and increase the fluid density as it simultaneously coextracted in a diffusion-controlled mechanism.

More importantly, with addition of co-extractant in Momordica charantia dried sample, it manages to extract target compound in this study, which is charantin as shown in Fig. 5.

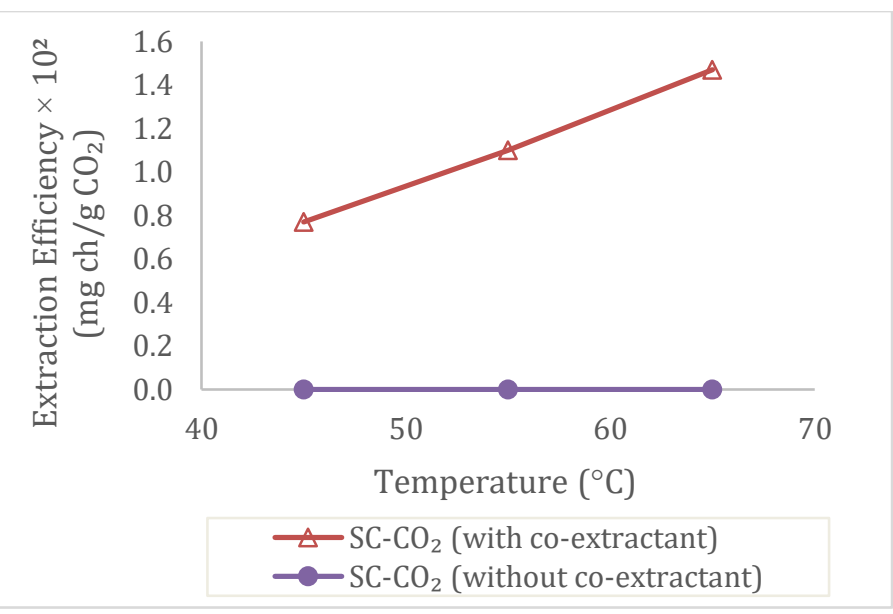

Fig. 5 Extraction efficiency of charantin in the extraction of Momordica charantia at various temperature at constant pressure, $20 \mathrm{MPa}$ using SC$\mathrm{CO}_{2}$ (with and without co-extractant) solvent.

Charantin is a molecule consists of a mixture (1:1) of two steroidal saponins compounds, sitosterol glucoside, and stigmasterol glucoside. The uniqueness of this molecule is that the steroidal part of it is highly soluble in non-polar solvents such as chloroform and dichloromethane. In contrast, the glucosides tail favours polar solvent such as ethanol or 
methanol due to its polarity and bulk structure $(\mathrm{MW}=578.494)$ (Pitipanapong et al., 2007). Therefore, $\mathrm{SC}-\mathrm{CO}_{2}$ (with co-extractant) is the suitable solvent to extract charantin in this study.

Similarly, a study done by Ruslan et al. (2015) and Ruslan et al. (2018) revealed the comparison between pure $\mathrm{SC}-\mathrm{CO}_{2}$ extraction and $\mathrm{SC}-\mathrm{CO}_{2}$ with methanol as the co-extractant in extracting catechin Catechin can be extracted with the help of $5 \%(\mathrm{v} / \mathrm{v})$ methanol as a coextractant compared with no addition of co-extractant $(0 \% \mathrm{v} / \mathrm{v}$ methanol). As catechin is a polar compound, it needs a polar solvent to extract the compound. It appears that the extractability of catechin was due to hydrogen bonding and interaction between hydroxyl group of catechin and methanol.

On the other hand, addition of co-solvent or co-extractant might not favour the extraction of target compound. As experienced byHatami et al. (2012) in their study, the addition of ethanol as a co-solvent gave negative impact in enhancing the recovery of diterpenic from spent coffee grounds due to mild polarity of the compound. The modified (addition of co-solvent) $\mathrm{SC}-\mathrm{CO}_{2}$ has higher affinity towards nonditerpenic compounds (other compound) which then only increase the total extract yield but not the diterpeninc yield.

\section{CONCLUSION}

In this study, we can conclude that mean particle size of $0.3 \mathrm{~mm}$ gave the highest extract yield of $3.32 \%$ and $1.34 \%$ respectively for with and without co- extractant respectively. Whereas, the value of $D_{e}$ at 0.3 $\mathrm{mm}$ mean particle size, with and without co-extractant are $8.820 \times 10^{-12}$ and $7.920 \times 10^{-12} \mathrm{~m}^{2} / \mathrm{s}$ respectively. Therefore, $0.3 \mathrm{~mm}$ is the best mean particle size to produce highest Momordica charantia extract yield and $D_{e}$ value in $\mathrm{SC}-\mathrm{CO}_{2}$ extraction with co-extractant. Besides, the addition of co-extractant in Momordica charantia dried sample prior extraction increased the extraction efficiency of target compound, charantin from Momordica charantia. Above all, the use of $\mathrm{SC}-\mathrm{CO}_{2}$ with co-extractant had proved its efficiency in extracting Momordica charantia in terms of extract yield and diffusion coefficient as well as charantin, the target compound.

\section{ACKNOWLEDGEMENT}

This work has been fully supported by Universiti Teknologi Malaysia for Research University Grant (Q.J130000.2509.16H87) and Research University Grant (Q.J130000.2509.14H23).

\section{REFERENCES}

Arsad, N. H., Yunus, M. A. C., Zaini, M. A. A., Rahman, Z. A., \& Idham, Z. (2016). Effect of operating conditions of supercritical carbon dioxide on piper betle leave oil yield and antioxidant activity. International Journal of Applied Chemistry, 12(4), 741-751.

Bakar, A. K. A., Ghani, A. A. A., Rahman, A. B., Zainuddin, A. A., Nadzri Jai, A., Chandran, A., Razali, A., Baharudin, A., Rosman, A., Mahadir Naidu, B., Chan, Y. Y., Jeevenathan, C., Siew Man, C., Eugene, C., Paiwai, F., Ismail, F., Othman, F., Mustapha, F., Rao, G., \& Zaini, Z. (2015). Nationa Health and Morbidity Survey 2015-VOLUME II : Non-Communicable Diseases, Risk Factors \& Other Health Problems.

Bartle, K. D., Clifford, A. A., Hawthorne, S. B., Langenfeld, J. J., Miller, D. J., \& Robinson, R. (1990). A model for dynamic extraction using a supercritical fluid. The Journal of Supercritical Fluids, 3(3), 143-149.

Ciurlia, L., Bleve, M., \& Rescio, L. (2009). Supercritical carbon dioxide coextraction of tomatoes (Lycopersicum esculentum L.) and hazelnuts (Corylus avellana L.): A new procedure in obtaining a source of natural lycopene. The Journal of Supercritical Fluids, 49(3), 338-344.

Crank, J. (1975). The Mathematics of Diffusion (2nd ed.). Bristol, England: Clarendon Press.

Danlami, J. M., Arsad, A., Zaini, M. A. A., \& Sulaiman, H. (2014). A comparative study of various oil extraction techniques from plants. Reviews in Chemical Engineering, 30(6), 605-626.

Danlami, J. M., Zaini, M. A. A., Arsad, A., \& Yunus, M. A. C. (2015). Solubility assessment of castor (Ricinus communis $\mathrm{L}$ ) oil in supercritical $\mathrm{CO}_{2}$ at different temperatures and pressures under dynamic conditions. Industrial Crops and Products, 76, 34-40.

Durante, M., Lenucci, M. S., D’Amico, L., Piro, G., \& Mita, G. (2014). Effect of drying and co-matrix addition on the yield and quality of supercritical
$\mathrm{CO}_{2}$ extracted pumpkin (Cucurbita moschata Duch.) oil. Food Chemistry, 148, 314-320.

Feisul, M. I., \& Azmi, S. (2013). National Diabetes Registry Report, Volume 1, 2009-2012. Retrieved from http://www.moh.gov.my/

Fuangchan, A., Sonthisombat, P., Seubnukarn, T., Chanouan, R., Chotchaisuwat, P., Sirigulsatien, V., Ingkaninan, K., Plianbangchang, P., \& Haines, S. T. (2011). Hypoglycemic effect of bitter melon compared with metformin in newly diagnosed type 2 diabetes patients. Journal of Ethnopharmacology, 134(2), 422-428.

Hadzri, H. M., Yunus, M. A. C., Zhari, S., \& Rithwan, F. (2014). The Effects of Solvents and Extraction Methods on the Antioxidant Activity of $P$. niruri. Jurnal Teknologi (Sciences \& Engineering), 68(5), 47-52.

Hatami, T., Cavalcanti, R. N., Takeuchi, T. M., \& Meireles, M. A. A. (2012). Supercritical fluid extraction of bioactive compounds from Macela (Achyrocline satureioides) flowers: Kinetic, experiments and modeling. The Journal of Supercritical Fluids, 65, 71-77.

Huang, Z., Yang, M.-J., Liu, S.-F., \& Ma, Q. (2011). Supercritical carbon dioxide extraction of Baizhu: Experiments and modeling. The Journal of Supercritical Fluids, 58(1), 31-39.

Kluson, D. P., Maksimovic, S., Ivanovic, J., \& Skala, D. (2012). CHISA 2012 supercritical extraction of essential oil from mentha and mathematical modelling- the influence of plant particle size. Procedia Engineering, 42, 1767-1777.

Liong, K. K., Wells, P. A., \& Foster, N. R. (1991). Diffusion in supercritical fluids. The Journal of Supercritical Fluids, 4(2), 91-108.

López-Padilla, A., Ruiz-Rodriguez, A., Reglero, G., \& Fornari, T. (2016). Study of the diffusion coefficient of solute-type extracts in supercritical carbon dioxide: Volatile oils, fatty acids and fixed oils. The Journal of Supercritical Fluids, 109, 148-156.

Medina, I. (2012). Determination of diffusion coefficients for supercritical fluids. Journal of Chromatography A, 1250, 124-140.

Melo, M. M. R. d., Silvestre, A. J. D., \& Silva, C. M. (2014). Supercritical fluid extraction of vegetable matrices: Applications, trends and future perspectives of a convincing green technology. The Journal of Supercritical Fluids, 92, 115-176.

Nasir, H. M. (2017). Bioactivities and Fitting Models of Quercus Infectoria Galls Extracts using Supercritical Carbon Dioxide. (Doctor of Philosophy (Bioprocess Engineering)), Universiti Teknologi Malaysia, Malaysia.

Özkal, S. G., \& Yener, M. E. (2016). Supercritical carbon dioxide extraction of flaxseed oil: Effect of extraction parameters and mass transfer modeling. The Journal of Supercritical Fluids, 112, 76-80.

Park, H.-S., Lee, H. J., Shin, M. H., Lee, K.-W., Lee, H., Kim, Y.-S., Kim, K. O., \& Kim, K. H. (2007). Effects of cosolvents on the decaffeination of green tea by supercritical carbon dioxide. Food Chemistry, 105(3), 10111017.

Pitipanapong, J., Chitprasert, S., Goto, M., Jiratchariyakul, W., Sasaki, M., \& Shotipruk, A. (2007). New approach for extraction of charantin from Momordica charantia with pressurized liquid extraction. Separation and Purification Technology, 52(3), 416-422.

Reverchon, E., Donsi, G., \& Sesti Osseo, L. (1993). Modeling of supercritical fluid extraction from herbaceous matrices. Industrial \& Engineering Chemistry Research, 32(11), 2721-2726.

Ruslan, M. S. H., Idham, Z., Nian Yian, L., Ahmad Zaini, M. A., \& Che Yunus, M. A. (2018). Effect of operating conditions on catechin extraction from betel nuts using supercritical $\mathrm{CO}_{2}$-methanol extraction. Separation Science and Technology, 53(4), 662-670.

Ruslan, M. S. H., Yunus, M. A. C., Idham, Z., Morad, N. A., \& Ali, A. (2015). Parametric Evaluation for Extraction of Catechin from Areca Catechu Linn Seeds using Supercritical $\mathrm{CO}_{2}$ Extraction. Jurnal Teknologi, 74(7), 87-92.

Samadi, S., \& Vaziri, B. M. (2017). Two-structured solid particle model for predicting and analyzing supercritical extraction performance. Journal of Chromatography A, 1506, 101-108.

Santos, R., Lu, T., Schlieper, L., King, M. B., \& Bastos, J. (1996). Extraction of useful components from herbs using supercritical $\mathrm{CO}_{2}$ : Experimental findings and data modelling. Process Technology Proceedings, 12, 399404.

Setapar, S. H. M., Yian, L. N., Yunus, M. A. C., Muhamad, I. I., \& Zaini, M. A. A. (2012). Extraction of rubber (hevea brasiliensis) seeds oil using supercritical carbon dioxide. Journal of Biobased Materials and Bioenergy, $6,1-6$

Shanmugapriya, R., \& Poornima, S. (2014). Detection of Charantin in the leaves and fruits of Momordica tuberosa (Cogn) Roxb and Momordica dioica (Roxb Ex Wild) by Analytical HPTLC. International Journal of Scientific and Research Publications, 4(6), 1-8.

Silva, M. V. d., \& Delgado, J. M. P. Q. (2011). Extraction of useful food and cosmetic ingredients of vegetable origin. Defect and Diffusion Forum, 312 315, 1161-1166.

Vladić, J., Zeković, Z., Jokić, S., Svilović, S., Kovačević, S., \& Vidović, S. (2016). Winter savory: Supercritical carbon dioxide extraction and 
mathematical modeling of extraction process. The Journal of Supercritical Fluids, 117, 89-97.

Wang, H.-Y., Kan, W.-C., Cheng, T.-J., Yu, S.-H., Chang, L.-H., \& Chuu, J.-J. (2014). Differential anti-diabetic effects and mechanism of action of charantin-rich extract of Taiwanese Momordica charantia between type 1 and type 2 diabetic mice. Food and Chemical Toxicology, 69, 347-356.

Yang, S. J., Choi, J. M., Park, S. E., Rhee, E. J., Lee, W. Y., Oh, K. W., Park, S. W., \& Park, C.-Y. (2015). Preventive effects of bitter melon (Momordica charantia) against insulin resistance and diabetes are associated with the inhibition of NF- $\mathrm{KB}$ and JNK pathways in high-fat-fed OLETF rats. The Journal of Nutritional Biochemistry, 26(3), 234-240.

Yasir, M., Sultana, B., Nigam, P. S., \& Owusu-Apenten, R. (2016). Antioxidant and genoprotective activity of selected cucurbitaceae seed extracts and LCESIMS/MS identification of phenolic components. Food Chemistry, 199, 307-313.

Yunus, M. A. C., Zhari, S., Haron, S., Arsad, N. H., Idham, Z., \& Ruslan, M. S. H. (2015). Extraction and Identification of Vitamin E from Pithecellobium Jiringan Seeds Using Supercritical Carbon Dioxide. Jurnal Teknologi, 74(7), 29-33.

Zhang, B., Xie, C., Wei, Y., Li, J., \& Yang, X. (2015). Purification and characterisation of an antifungal protein, MCha-Pr, from the intercellular fluid of bitter gourd (Momordica charantia) leaves. Protein Expression and Purification, 107, 43-49. 